\title{
¿SECULARIZACIÓN O REFORMA? LOS ORÍGENES RELIGIOSOS DEL MATRIMONIO CIVIL EN MÉXICO
}

\author{
POR \\ PABLO MiJANGOS Y GoNZÁLEZ \\ Centro de Investigación y Docencia Económicas (CIDE) \\ pablo.mijangos@cide.edu
}

\begin{abstract}
RESUMEN
Apoyado en la tesis sobre la "Reforma imprevista" de Brad S. Gregory, este ensayo sostiene que la Ley mexicana del Matrimonio Civil de 1859 debe interpretarse como un esfuerzo de reforma social concebido en un marco fundamentalmente religioso -aunque eventualmente haya contribuido a la secularización de la vida social. Para demostrar este punto, el ensayo analiza el pensamiento liberal mexicano acerca de la relación entre el matrimonio, la familia y la moralidad cívica, según fue desarrollado en obras académicas, panfletos y piezas periodísticas entre 1821 y 1859 . Estas fuentes muestran claramente que, para los liberales mexicanos, una de las principales fuentes del desorden social en el México republicano era la ineficaz y abusiva administración clerical del sacramento del matrimonio, la cual había provocado una disminución dramática de parejas casadas y por lo tanto una proliferación de hijos ilegítimos. Bajo esta óptica, el control civil del matrimonio era un instrumento privilegiado para llevar a cabo una reforma cristiana de la sociedad -una tarea que, desde el punto de vista liberal, sólo podía ser llevada a cabo por el Estado.
\end{abstract}

PALABRAS CLAVE: Matrimonio civil, secularización, reforma, anticlericalismo, obvenciones parroquiales.

\section{SECULARIZATION OR REFORMATION? THE RELIGIOUS ORIGINS OF CIVIL MARRIAGE IN MEXICO}

\begin{abstract}
Drawing on the insights of Brad S. Gregory's The Unintended Reformation, this article argues that Mexico's 1859 Law on Civil Marriage intended first and foremost to reform Mexican society within an essentially religious framework, and only as an unintended consequence did it contribute to the secularization of social life. To support this argument, the article reviews liberal ideas on the relationship between marriage, the family and civic morality, as developed in academic treatises, pamphlets, and journalistic pieces published between 1821 and 1859. These sources clearly show that, for Mexican liberals, one of the main causes of social disorder in early republican Mexico was the clergy's abusive administration of the sacrament of marriage, which had resulted in a dramatic decrease of married couples and the ensuing proliferation of illegitimate children. Under this light, civil marriage was a privileged instrument for a Christian reform of society -a task which seemingly could only be conducted by the liberal state.
\end{abstract}

KEY WORDS: Civil marriage, secularization, reform, anticlericalism, parish dues.

$\begin{array}{ll}\text { Recibido/Received } & 19-12-2014 \\ \text { Aceptado/Accepted } & 01-10-2015\end{array}$

El 23 de julio de 1859, dos semanas después de haber decretado "la más perfecta independencia entre los negocios del Estado y los puramente eclesiásticos", el presidente Benito Juárez promulgó la primera ley sobre el matrimonio civil en México. En términos generales, esta ley declaraba al matrimonio como un contrato que sólo podía contraerse lícita y válidamente ante las autoridades civiles, si bien reconocía la libertad de los contrayentes para "recibir las bendiciones de los ministros de su culto". Pese a su evidente importancia en la redefinición de las relaciones entre el poder civil y el religioso, esta pieza fundamental de las llamadas "Leyes de Reforma" no ha sido un tema frecuentado por la historiografía, ni siquiera por los estudios de género. ${ }^{1}$ Una razón de este desinterés historiográfico radica precisamente en que, por su claridad y trascendencia, la ley del matrimonio civil parece no necesitar de mayor explicación: es el ejemplo paradigmático del afán secularizador que tradicionalmente

\footnotetext{
1 La historiografía sobre la Ley del Matrimonio Civil es muy parca. El mejor estudio disponible es Adame Goddard, J. 2004. El matrimonio civil en México (1859-2000): 1-10 México: UNAM.
} 
se ha atribuido al liberalismo mexicano del siglo XIX. La historiadora Anne Staples, por ejemplo, enmarca esta ley en "una tendencia a reducir la esfera de influencia y actividades de la Iglesia, de modo que hubiera, sobre todo en los espacios públicos, mayores facilidades para las actividades mundanas". ${ }^{2}$ De modo similar, el jurista católico Carlos Warnholtz afirma que el matrimonio civil "es fruto y consecuencia de la secularización de la sociedad, un postulado del Estado laico, pluralista [y] aconfesional". ${ }^{3}$

El principal problema con este verdadero lugar común de la historiografía es que no permite entender varios aspectos característicos de la Ley del Matrimonio Civil de 1859, como el mantenimiento de la indisolubilidad conyugal o la extensa "epístola" sobre los derechos y deberes de los esposos, cuyo tono moralizante evoca las cartas de San Pablo a los efesios. ¿Por qué una ley secularizadora, que supuestamente buscaba abrir mayores espacios a la libertad individual y al disfrute "del aquí y del ahora", mantuvo los rasgos más conservadores del matrimonio canónico? ¿Por qué no siguió el modelo de las leyes revolucionarias francesas de 1791 y 1792, que sí permitieron el divorcio e incluso limitaron la autoridad patriarcal en el ámbito doméstico? ${ }^{4}$ Más aún, ¿por qué una reforma "individualista” recalcó que hombre y mujer no existen "en la persona sola, sino en la dualidad conyugal", exigiendo además que los casados fueran "sagrados el uno para el otro"? Al no contar con una respuesta satisfactoria a estas preguntas, la historiografía ha preferido buscar explicaciones al "fracaso" del proyecto secularizador supuestamente encarnado en la Ley del Matrimonio Civil. Ana Lidia García Peña, por ejemplo, reconoce que las mujeres mexicanas no se beneficiaron de la reforma de 1859, pero, en lugar de cuestionar si el objetivo de la ley había sido efectivamente beneficiarlas, argumenta que éstas apenas habían iniciado "el lento camino de su autoconstrucción positiva", por lo que aún no estaban preparadas para "ejercitar el derecho a contractuar en condiciones de igualdad". La ley fracasó, entonces, porque el "ideal teórico de la libre decisión" se prestaba para abusar de mujeres "pobres e ignorantes", atrapadas en su "condición de subordinadas". ${ }^{5}$

El presente ensayo pretende ofrecer una respuesta alternativa a estas preguntas mediante el cuestionamiento de la premisa central de esta discusión: el supuesto afán secularizador del liberalismo mexicano de las décadas intermedias del siglo XIX. ${ }^{6}$ ¿Es correcto asumir que los liberales de la

\footnotetext{
2 Staples, A. 2001. "El matrimonio civil y la epístola de Melchor Ocampo, 1859", en Pilar Gonzalbo, (coord.), Familias iberoamericanas. Historia, identidad y conflictos. 221-222. México: El Colegio de México. En el mismo sentido, véase Núñez Becerra, F. 2011. “Mujeres y matrimonio civil vistos por las Leyes de Reforma", en Celia del Palacio Montiel, coord., México durante la guerra de Reforma. Tomo II. Contextos, prácticas culturales, imaginarios y representaciones, Xalapa: Universidad Veracruzana: 139-153.

3 Warnholtz Bustillos, C. 1996. Manual de derecho matrimonial canónico: 67. México: Universidad Pontificia de México.

4 Al respecto, véase la excelente obra de Desan, S. 2004. The Family on Trial in Revolutionary France, Berkeley: University of California Press.

5 García Peña, A. L. 2006. El fracaso del amor. Género e individualismo en el siglo XIX mexicano: 15-19, 235-238. México: El Colegio de México / Universidad Autónoma del Estado de México.

6 Para una presentación esquemática de las principales teorías y definiciones de la secularización, véase Lida, M. 2007. “Secularización:
}

Reforma deseaban expulsar a la religión del espacio público y confinarla a la esfera privada de los individuos? Tomando como ejemplo representativo la Ley del Matrimonio Civil, este ensayo sostiene que las Leyes de Reforma, lejos de obedecer a un proyecto secularizador, buscaban convertir al Estado en el agente de la moralización y recristianización del pueblo mexicano -un pueblo que, a juicio de los liberales, se había corrompido profundamente a causa del mal ejemplo y las prácticas abusivas del clero católico. Bajo esta óptica -inspirada en las obras de Brad S. Gregory, Dale Van Kley y Pamela Voekel sobre los orígenes religiosos de las revoluciones modernas ${ }^{7}{ }^{7}$ resulta más fácil advertir que la Ley del Matrimonio Civil pretendía originalmente reformar a la sociedad mexicana en el marco de la moral cristiana, y que el arranque de la secularización fue una consecuencia imprevista, y de largo plazo, de esta reforma religiosa. Creo que esta inversión en el orden de los factores - primero fue la reforma y después la secularización- permite entender mejor las peculiaridades de la ley de 1859 y refleja con mayor precisión el modo en que los liberales mexicanos se describieron a sí mismos.

Metodológicamente, este ensayo es un ejercicio de historia intelectual: se trata de una relectura de la Ley del Matrimonio Civil a la luz de las ideas liberales sobre el matrimonio, la familia, la moralidad y el orden social. Las fuentes utilizadas para reconstruir este corpus ideológico son tres obras representativas de la doctrina jurídica de la época, y, sobre todo, una selección de artículos periodísticos, disertaciones, intervenciones parlamentarias, representaciones y circulares firmadas por seis de los principales líderes de la generación de la Reforma: Ponciano Arriaga, Ignacio Vallarta, Manuel Payno, Francisco Zarco, Melchor Ocampo y Manuel F. Ruiz. Ya fuera en las tribunas del Congreso Constituyente de 1856-57, o bien sirviendo como secretarios de Estado durante los gobiernos de Juan Álvarez, Ignacio Comonfort y Benito Juárez (1855-61), estos seis personajes contribuyeron a la realización de un programa de reformas que fue gestándose a lo largo de varias décadas y que de ningún modo fue ajeno a la tradición cultural que todos compartían: el catolicismo. Cabe aclarar desde ahora que las fuentes seleccionadas no siempre describen con precisión la realidad efectiva del pueblo que los liberales pretendían reformar: sin duda sería necesario completar este estudio con un análisis más cuidadoso de la historia social e institucional del matrimonio en el México independiente, que mostrara el modo en que la experiencia concreta dio forma al discurso ideológico. Para ello, sin embargo, resulta necesario develar primero la estructura y la lógica de un discurso que, a mi juicio, no se entiende bien mediante las categorías elaboradas por la ciencia social del siglo xx.

doctrina, teoría y mito. Un debate desde la historia sobre un viejo tópico de la sociología" Cuadernos de Historia. Serie Economía y Sociedad, no 9: 43-63.

7 Gregory, Brad S. 2012. The Unintended Reformation: How a Religious Revolution Secularized Society, Cambridge: Harvard University Press; Van Kley, D. K. 1996. The Religious Origins of the French Revolution: From Calvin to the Civil Constitution, 1560-1791, New Haven: Yale University Press; Voekel, P. 2002. Alone before God: The Religious Origins of Modernity in Mexico, Durham: Duke University Press. 
A riesgo de caer en contradicción, me parece conveniente comenzar este ensayo analizando las propuestas secularizadoras de José María Luis Mora, el principal ideólogo de la primera generación liberal, cuyas obras tuvieron una profunda influencia en las sucesivas reconstrucciones historiográficas del liberalismo mexicano. Fue Mora, en efecto, quien postuló con mayor elocuencia la necesidad de confinar al clero en una "órbita puramente espiritual" y reconocer al matrimonio como un mero contrato civil. En su Revista política de las diversas administraciones que la República Mejicana ha tenido hasta 1837, publicada a los tres años de su exilio en París, Mora explicaba que una de las "convicciones íntimas" del programa político de la administración de Valentín Gómez Farías (1833-34) había sido la de suprimir "todas las leyes que atribuyen al Clero el conocimiento de negocios civiles", pues éste era un poder "degenerado", en perpetua rivalidad con el soberano temporal y completamente ajeno a los "lazos de familia, primero y principal vínculo del hombre con la sociedad". ${ }^{8}$ Según Mora, la legislación vigente sobre el matrimonio en México era una "mezcla confusa de disposiciones civiles y eclesiásticas difícil de aplicarse", cuya ejecución estaba "exclusivamente confiada a los ministros de culto". De ahí que "el acto más importante de la vida" se hiciera "no sólo sin intervención, sino aún sin conocimiento del magistrado civil", cosa que no sucedía en las naciones civilizadas. ${ }^{9}$ Para corregir entonces el "abandono inexplicable" en que se hallaba el matrimonio, Mora proponía distinguir claramente aquello que le correspondía normar a cada potestad, considerando los fines de la institución y las diferencias entre el ámbito civil y el sacramental:

Siendo como es el matrimonio una necesidad social que ocurre con frecuencia, la Sociedad no puede prescindir del derecho de arreglarlo, estableciendo cuanto pueda requerirse, para su celebración en orden a la habilidad o impedimento de las personas; para su duración fijando y garantizando las obligaciones de los casados entre sí, y con la prole que tuvieren; para su rescisión designando los casos y situaciones que la exijan; los arreglos que deban seguirla, y los tribunales civiles que deban pronunciarla [...] Los negocios religiosos no se arreglan sino de conciencia a conciencia; y la bendición nupcial no tiene valor si no reposa sobre la fe del que la confiere y de los que la solicitan. El poder civil incompetente para crear e incapaz para destruir esta convicción, tampoco debe reglarla. Para él, el matrimonio no es ni debe ser otra cosa que un contrato civil, que celebrado bajo las formas y condiciones que la ley exija, y firmado y consentido por las partes, debe surtir sus efectos civiles en orden a los derechos y obligaciones de los contrayentes entre sí, de la prole, y de la sociedad entera. Lo demás es negocio de la conciencia de cada uno, que se manejará en esto según las reglas que ella le dicte. ${ }^{10}$

Salvo por la importante sugerencia de introducir la "rescisión" del contrato matrimonial, es claro que la propuesta de Mora -indudablemente secularizadora- guarda una fuerte similitud con la ley del matrimonio civil de 1859.

8 Mora, J. M. L. 1837. "Revista política de las diversas administraciones que la República Mejicana ha tenido hasta 1837", en Obras sueltas de José María Luis Mora, ciudadano mejicano. Tomo primero: 91, 105, 127. París: Librería de la Rosa.

9 Ibídem, 128-129.

10 Ibídem, 129-130.
Parecería entonces que, por lo menos desde 1833, la secularización del matrimonio habría sido un objetivo central de los sucesivos proyectos liberales, cuya realización se pospuso por la tenaz resistencia del clero y del partido conservador. El problema de esta lectura es que, en los hechos, los supuestos herederos del programa de Mora no volvieron a proponer una separación tajante entre el contrato civil y el sacramento matrimonial, ni siquiera durante los debates más álgidos del Congreso Constituyente de 1856-57. ¿Cómo explicar esta falta de continuidad en un aspecto tan importante del ideario liberal? Una posible explicación de la distancia temporal entre la propuesta de Mora y la ley juarista del matrimonio civil consistiría en asumir que, después del fracaso estrepitoso de la intentona reformista de Valentín Gómez Farías en 1834, muchos liberales optaron por moderar los rasgos más radicales de su programa, esperando pacientemente a que llegara el momento oportuno para su realización. Otra posible explicación, a mi juicio más sólida y fácil de documentar, es que la propuesta de Mora -escrita desde el exilio en un momento de radicalización e inocultable amargura personal- no reflejaba necesariamente el sentir dominante entre los liberales mexicanos de la primera mitad del siglo XIX, lo cual permitiría entender por qué el camino a la separación fue mucho más sinuoso de lo que tradicionalmente han asumido los historiadores.

Antes de seguir adelante, es importante analizar primero hasta qué punto era correcta la descripción que hacía Mora del derecho matrimonial vigente en el México republicano. Ciertamente, desde el Concilio de Trento en el siglo XVI, los dos requisitos fundamentales para la validez del matrimonio entre católicos eran el libre consentimiento de los contrayentes y, de modo particular, su celebración en presencia de un sacerdote y por lo menos dos testigos. ${ }^{11}$ Ello explica que, en el mundo católico, buena parte de la doctrina sobre las formalidades, requisitos, impedimentos y efectos del matrimonio fuera desarrollada por canonistas a partir de principios teológicos y de la praxis cotidiana de los tribunales eclesiásticos, en los que se ventilaban la mayor parte de los litigios relacionados con el matrimonio y la vida familiar. Esto no significa, sin embargo, que su regulación estuviera "exclusivamente confiada a los ministros de culto," como afirmaba Mora. En realidad, ni el Concilio ni los pontífices lograron excluir a los soberanos seculares de una materia que siempre había sido considerada trascendental para el orden y bienestar de los reinos. Los monarcas españoles, por ejemplo, insistieron una y otra vez en el derecho de los padres a oponerse a la realización de "matrimonios desiguales", principio que sería codificado formalmente en la Pragmática sanción sobre matrimonios de $1776 .{ }^{12}$ La obligación de los contrayentes de pedir el consejo y consenti-

11 Sobre los principios del matrimonio tridentino, véase Albani, B. 2008. "El matrimonio entre Roma y la Nueva España, historia y fuentes documentales (siglos XVI-XVII)", en Doris Bieñko de Peralta y Berenise Bravo Rubio, coords., De sendas, brechas y atajos. Contexto y crítica de las fuentes eclesiásticas, siglos XVI-XVIII: 167-174. México: INAH / CONACULTA.

12 Al respecto, véase Saether, S. A. 2003. "Bourbon Absolutism and Marriage Reform in Late Colonial Spanish America", The Americas, vol. 59, no. 4: 477-483. 
miento paterno (que se transformaba en la obligación de obtener dicho consentimiento en el caso de los hijos menores de 25 años y las hijas menores de 23) se mantuvo vigente después de la Independencia, al punto que la edición mexicana del popular Diccionario razonado de legislación civil, penal, comercial y forense de Joaquín Escriche (1837) todavía enseñaba que, frente a la negativa paterna, la "primera autoridad política de la provincia" tendría la facultad última de conceder o negar el permiso para contraer matrimonio. Si este requisito cardinal de la legislación civil no era debidamente satisfecho, los contrayentes podían ser desheredados y el celebrante se hacía reo de las penas de expatriación y confiscación de bienes. ${ }^{13}$

Es importante advertir que la descripción de Mora también evita mencionar que los tribunales civiles podían intervenir decisivamente en litigios matrimoniales mediante los llamados "recursos de fuerza y protección", los cuales permitían a cualquier persona solicitar la protección de la justicia secular contra posibles abusos cometidos por las autoridades eclesiásticas, aún cuando éstas actuaran en ejercicio de su propia jurisdicción. Un ejemplo de esta modalidad de intervención es el célebre juicio promovido por el acaudalado empresario José María Flores ante la Suprema Corte de Justicia de la Nación en septiembre de 1846, en el que se denunció la confabulación del gobernador del Distrito Federal y del Dr. José María Aguirre, "defensor de matrimonios" del Arzobispado de México, para sustraer a la hija de Flores de la residencia paterna y facilitar de esa manera su ansiada -y escandalosa- unión con un antiguo empleado de la familia, quien al parecer era protegido del presbítero Aguirre. No es momento de narrar los pormenores de esta historia digna de telenovela, pero vale la pena subrayar que, a lo largo del juicio, centrado en el respeto a la autoridad paterna y el destino de la cuantiosa herencia de Flores, se defendió explícitamente la legitimidad de la jurisdicción extraordinaria de los tribunales civiles en las controversias matrimoniales, por la vía del recurso de fuerza. Así lo expresó el distinguido abogado Juan Rodríguez de San Miguel, a quien Flores encomendó la defensa de su causa:

Todos, tanto eclesiásticos como seculares, tienen el derecho de implorar la protección de la autoridad pública, para el obsequio y observancia de las disposiciones canónicas [...] Quede pues asentado que [el recurso de fuerza] es conocidísimo, fundado, de expreso derecho, constante en terminantes doctrinas de los autores, que lejos de causar risa, se han captado el respeto de los jurisconsultos nacionales y extranjeros, y finalmente que está muy distante de hacer época por desconocido e inaudito. Podría el recurso ser injusto; pero de ninguna manera extraño a la materia, desconocido y extravagante. ${ }^{14}$

13 Escriche, J. 1837. Diccionario razonado de legislación civil, penal, comercial y forense: 419-420. México: Imprenta de Galván a cargo de Mariano Arévalo.

14 Informe que el L. Juan Rodríguez de San Miguel, hizo en la E. Primera Sala de la Suprema Corte de Justicia, el 22 de Septiembre de 1846 , en el recurso de fuerza interpuesto por D. José M. Flores, contra la dispensa de las públicas moniciones en el matrimonio que expresa, para que en él se observasen acerca de éstas las disposiciones del Tridentino, Bulas Pontificias y leyes civiles muy expresas: 36-37. México: Imprenta de José Mariano Lara, 1846.
La concurrencia jurisdiccional de la Iglesia y el Estado en los asuntos matrimoniales estaba en perfecta consonancia con la doctrina prevaleciente sobre la naturaleza jurídica de esta institución. A diferencia de Mora, la inmensa mayoría de los juristas del México de la primera mitad del siglo XIX consideraba que el matrimonio era un contrato sui generis, tanto por su dimensión sacramental como por su enorme relevancia en los destinos de la sociedad. La Librería de Jueces, abogados y escribanos, mejor conocida como el Febrero mejicano (1834), recoge la definición de matrimonio utilizada con mayor frecuencia en la literatura jurídica de la época. Citando al tratadista francés Robert-Joseph Pothier, el Febrero presenta el matrimonio como un "contrato celebrado con las formalidades que han prescrito las leyes, por el cual un hombre y una mujer, hábiles para contraerlo, se obligan recíprocamente a permanecer toda su vida en la unión que debe existir entre un esposo y una esposa", añadiendo más adelante que "cuando Jesucristo elevó a sacramento el contrato matrimonial, no alteró en nada su naturaleza". ${ }^{15}$ En términos muy similares, el Diccionario de Escriche lo define como la "sociedad legítima del hombre y de la mujer, que se unen con vínculo indisoluble, para perpetuar su especie, ayudarse a llevar el peso de la vida, y participar de una misma suerte", del que conocían los jueces eclesiásticos en cuanto sacramento y los jueces seculares en "las causas relativas al contrato y sus efectos civiles". ${ }^{16}$

Es importante advertir que un rasgo único del "contrato matrimonial" era su carácter indisoluble, cosa que lo hacía distinto a cualquier otro acuerdo de voluntades. Se pueden citar dos ejemplos significativos de la vigencia de esta doctrina a mediados del siglo XIX. En su "Disertación presentada en la cátedra de derecho civil" de la Universidad de Guadalajara el 1ㅇ de marzo de 1850, el joven estudiante Ignacio Vallarta -quien participaría en el Congreso Constituyente seis años después- explicaba que el enlace conyugal era la "unión más perfecta que pueda haber entre dos personas", prescrita por el Derecho Natural para "facilitar el cumplimiento del sagrado precepto crescite et multiplicamini". ${ }^{17}$ Siendo el vínculo "más conveniente a las necesidades y a las circunstancias de las familias, y el más favorable a los individuos en la generalidad de la especie", el matrimonio tenía una "naturaleza muy diversa" a la de los contratos consensuales, en los que "cada uno puede rescindir el contrato, sin perjuicio de tercero". ${ }^{18}$ En el caso de la unión conyugal, los bienes que tutelaba eran de tal magnitud que su permanencia podía ser considerada de interés público:

15 Febrero mejicano, o sea la librería de Jueces, abogados y escribanos, que refundida, ordenada bajo nuevo método, adicionada con varios tratados y con el título de Febrero Novísimo, dio a luz D. Eugenio de Tapia, nuevamente adicionada con otros diversos tratados, y las disposiciones del Derecho de Indias y del Patrio, por el Lic. Anastasio de la Pascua, tomo I: 124-125. México: M. Galván Rivera, 1834.

16 Escriche, 1837: 419 y 421.

17 Ignacio Vallarta, "Borrador de la Disertación presentada en la cátedra de Derecho Civil en 1ㅇ de marzo de 1850", en Obras completas del C. Lic. Ignacio L. Vallarta, tomo sexto, México: José Joaquín Terrazas e hijas, imp., 1897: 304-306.

18 Ibídem, 318-319. 
¿Quién es el perjudicado en [el matrimonio] con la separación de los cónyuges? Los hijos que no se educan de la manera debida. ¿No hay hijos? Pues todavía hay tercero perjudicado: la mujer. "El matrimonio, dice M. Bonald, es una sociedad de la que sale el hombre en caso de disolución, con toda su autoridad; pero la mujer no puede salir con toda su dignidad, porque de todo lo que ella ha llevado a esta sociedad, no puede sacar más que su dinero. ¿Y no es altamente injusto que una mujer entrada en la familia con la juventud y la belleza, salga de ella con la vejez?" He aquí, pues, el tercer perjudicado; pero se nos dirá, en el caso propuesto ella renuncia, no hace caso de todos los daños que le haya ocasionado el matrimonio; lo único que quiere, es que se disuelva. Pues todavía hay dañado: la sociedad. Ella sintiéndose conmovida hasta sus cimientos por el permiso del divorcio a petición de las partes, que es tal vez de los más dañosos para la sociedad, se levanta, habla contra tal abuso, y nunca lo permitirá, porque nunca dejará que se le ultraje. ${ }^{19}$

Con argumentos muy similares, los diputados liberales del Congreso Constituyente de 1856-57 también insistieron en la peculiaridad del matrimonio frente a los demás contratos civiles. Si bien el proyecto de Constitución no contemplaba esta materia, la discusión surgió a raíz del segundo párrafo del artículo 5으, en el cual se dispuso que "la ley no puede autorizar ningún contrato que tenga por objeto la pérdida o el irrevocable sacrificio de la libertad del hombre, ya sea por causa de trabajo, de educación o de voto religioso". A juicio del diputado conservador Marcelino Castañeda, dicha redacción podía interpretarse en el sentido de que la nueva Constitución no autorizaba el matrimonio, ya que éste era un "contrato que importa el sacrificio de la libertad del hombre para toda la vida". ${ }^{20}$ Aunque el diputado liberal José María Mata aclaró que el artículo no se refería al matrimonio, otros diputados consideraron necesario disipar cualquier duda respecto a la continuidad de la doctrina vigente en un tema "esencial para la existencia de la familia, para el mantenimiento de la moral, para el buen orden de la sociedad y para la felicidad de la mujer". ${ }^{21}$ Francisco Cendejas, por ejemplo, subrayó que no había razón alguna para censurar la indisolubilidad del matrimonio, pues, "como contrato [éste] es diferente de todos los contratos y por su objeto y por su naturaleza tiene muy distinto carácter". ${ }^{22}$ Curiosamente, el defensor más elocuente de la doctrina tradicional fue el diputado "puro" Ponciano Arriaga, quien denunció al divorcio como fuente segura de "escándalos e inmoralidad". Según el líder de la facción más radical del Congreso, el matrimonio indisoluble no implicaba nunca la "esclavitud" de los cónyuges y menos aún de la mujer, pues la "civilización cristiana" -de la que México formaba parte- siempre había sostenido que "la más hermosa y la más noble mitad del género humano" era "enteramente libre" y sólo sacrificaba "algo de su libertad" en aras del amor, la maternidad y el "bien de la sociedad". ${ }^{23}$

\footnotetext{
19 Ídem.

20 Zarco, F. 1956. Historia del Congreso Extraordinario Constituyente, 1856-1857: 512. México: El Colegio de México.

21 Ibídem, 516.

22 Ibídem, 514-515.

23 Ibídem, 518.
}

Queda claro, entonces, que, por lo menos hasta 1856, la naturaleza jurídica del matrimonio -como sacramento y contrato civil sui generis- no era realmente objeto de debate. La verdadera discusión era otra: asumiendo que el matrimonio concernía tanto a la Iglesia como al Estado, chasta dónde podían llegar las autoridades civiles en su deber de asegurar la observancia de los cánones y la estabilidad del orden doméstico y social? ¿Podían reemplazar al clero si éste no cumplía adecuadamente sus deberes en una materia tan grave? Esta discusión se presentó por primera vez a finales de 1821, ante el riesgo de un eventual cisma por el rechazo inicial de la Santa Sede a la independencia de México. En la ciudad de Puebla, por ejemplo, el publicista liberal Juan Nepomuceno Troncoso tradujo y publicó un Dictamen de la facultad de teología de Friburgo, sobre el valor de los Sacramentos administrados por los Sacerdotes juramentados en la Francia, cuya versión original apareció en el contexto del cisma provocado por la Constitución Civil del Clero francés de 1790. Esta polémica obra ya contenía un principio fundamental que sería defendido por la mayoría de los liberales mexicanos hasta la época de la Reforma, y que podría formularse de la siguiente manera: cuando el clero no estaba dispuesto a satisfacer las necesidades sacramentales de los fieles, la autoridad civil tenía el derecho y la obligación de garantizar la debida celebración de bautizos, confirmaciones y matrimonios, mismos que se regirían por las leyes de la nación en todo lo que no fuera contrario a la fe católica. ${ }^{24}$

Aunque los temores a un cisma disminuyeron tras los primeros acercamientos entre México y la Santa Sede, las denuncias liberales contra la corrupción e indolencia del clero aumentaron en número e intensidad durante las décadas siguientes. Por lo general, la historiografía ha explicado la crítica liberal contra los múltiples privilegios del clero como parte de un programa modernizante y secularizador, sin darse cuenta de que los progresos del anticlericalismo estaban vinculados, más bien, al escándalo de los liberales frente a la inmoralidad que supuestamente reinaba en la sociedad mexicana de la primera mitad del siglo XIX. Para entender por qué los liberales denunciaban al clero como la raíz de todos los males del México independiente y por qué anhelaban una mayor intervención del Estado en la administración del sacramento nupcial, es necesario partir de una premisa frecuentemente ignorada por los historiadores: durante la primera mitad del siglo XIX, liberales y conservadores por igual asumían la existencia de un vínculo profundo entre el matrimonio, la familia y el orden social, concebido en los mismos términos de la teología moral católica. En el texto de Ignacio Vallarta citado previamente, por ejemplo, se asume categóricamente que "la sociedad corre la suerte de la familia". ${ }^{25}$ De ahí que la introducción del divorcio fuera vista como una amenaza no sólo contra la familia, sino contra la sociedad entera:

[La disolubilidad conyugal] sembraría, sin duda, en la parte donde fuera admitida, los odios entre los cónyuges, odios que se transmitirían hasta los hijos; las más

24 Al respecto, véase Rosas Salas, S. F. 2013. La Iglesia mexicana en tiempos de la impiedad: Francisco Pablo Vázquez, 1769-1847: 130-132. Tesis de doctorado en Ciencias Humanas, El Colegio de Michoacán.

25 Vallarta, 1897: 311. 
licenciosas costumbres en todos los miembros de la sociedad; hace perder a los pueblos su fuerza moral: en una palabra, ella removiendo a la sociedad desde sus fundamentos, la precipita en el más espantoso desorden, en un caos perfecto, en la corrupción más horrorosa. ${ }^{26}$

El lenguaje exasperado de Vallarta -“las más licenciosas costumbres", "el más espantoso desorden", "la corrupción más horrorosa"- tenía una resonancia especial para una generación de mexicanos que había sufrido en carne propia el declive político y económico de su joven nación. Ciertamente, los signos de una crisis social profunda no eran difíciles de advertir: todos los testimonios de la época recogen noticias sobre la violencia política y la debilidad de los gobiernos, la inseguridad de los caminos, el estancamiento de la agricultura, la disminución del comercio, y la multiplicación de bandoleros, vagos y trashumantes. Para los liberales, estos signos de crisis estaban vinculados a fenómenos domésticos y demográficos que les provocaban una gran ansiedad. Aunque la mayor parte de la información disponible se refiere al ámbito urbano, existe evidencia de un claro desequilibrio entre el número de hombres y mujeres (en 1848, el 59\% de los habitantes de la Ciudad de México eran mujeres), así como de una baja tasa de matrimonios durante las décadas intermedias del siglo XIX, lo cual daba lugar a un gran número de relaciones en concubinato, mujeres solteras e hijos ilegítimos, es decir, un orden familiar en crisis. ${ }^{27}$

La preocupación liberal frente a los desajustes del ámbito doméstico se ilustra perfectamente con un revelador artículo de Manuel Payno sobre el "celibato femenino", publicado en EI Siglo XIX el 29 de diciembre de 1843. El artículo comenzaba citando algunas frases que Payno había escuchado en distintas conversaciones durante los años recientes:

Hace dos años oí decir a una joven de diecisiete: "Yo quiero un marido casi tonto para dominarlo". Una hermana más joven le contestó: "Yo no me caso porque quiero ser libre" [...] A estas máximas, escritas en mi libro verde, agrego hoy esta otra, que oí a una señorita de dieciocho años a las ocho menos cuarto de la noche del viernes último, 12 de mayo de 1843; dijo así: "La felicidad de la mujer consiste en permanecer soltera". ${ }^{28}$

Escandalizado ante dichas expresiones, que por lo visto eran cada vez más frecuentes, Payno recordaba

\section{Ibídem, 312-313.}

27 Véase Arrom, S. 1985. The Women of Mexico City, 1790-1857: 105-141. Stanford: Stanford University Press; y García Peña, 2006: 22-23. Esta crisis del orden familiar, sin embargo, no era un fenómeno nuevo del siglo XIX. Los estudios existentes sobre los siglos XVII y XVIII muestran que, en muchas poblaciones, entre el 20 y el $40 \%$ de las uniones entre hombre y mujer no se formalizaban sacramentalmente, lo cual se reflejaba también en altos índices de ilegitimidad. Véase Gonzalbo, P. (coord.). 1991. Familias novohispanas: siglos XVI al XIX, México: EI Colegio de México; Gonzalbo, P. y C. Rabell, (coords.). 1996. Familia y vida privada en la historia de Iberoamérica, México: El Colegio de México / UNAM; Lavrin, A. (coord.). 1989. Sexuality and Marriage in Colonial Latin America, Lincoln: University of Nebraska Press; y Carbajal, D. 2008. La población en Bolaños, 1740-1848. Dinámica demográfica, familia y mestizaje, Zamora: El Colegio de Michoacán.

28 Manuel Payno, "Celibato femenino" (publicado por primera vez en EI Siglo XIX, 29 de diciembre de 1843), en Boris Rosen, comp., 1996. Manuel Payno. Obras completas, tomo XIV: 269. México: CONACULTA. inmediatamente a sus lectores que la "soltería" era el "cáncer de las costumbres" y la "gangrena de la población", un mal terrible cuya responsabilidad no recaía exclusivamente en los hombres que evitaban el compromiso matrimonial. Payno advertía que la libertad de las jóvenes solteras era simplemente "la esclavitud de los caprichos y los placeres", un espejismo que convertiría a sus presas en un "árbol sin fruto", mujeres privadas de su "corona de madre" y condenadas a recorrer solas "el desierto de la vida". ${ }^{29}$ La cohabitación fuera del matrimonio, en este sentido, era una práctica peligrosa e indefendible, pues sólo enseñaba a las mujeres a tener "muchos novios y ningún marido":

[...] lo cierto es que la soltería hace progresos rápidos, sorprendentes y devastadores. Si naciesen los hombres como la maloja en los campos; si la especie humana pudiese conservarse como la de los lobos sin el matrimonio legal y religioso, podríamos también economizar gastos y ceremonias, y aún cuando el matrimonio no fuese necesario, siempre sería decente. Rodéese de prestigio una unión ilegítima, ennoblézcase al hijo espúreo, pero ¿cómo se ennoblece esa palabra: amancebamiento? ¿No es verdad que es innoble, baja, escandalizadora?. ${ }^{30}$

Aquel mismo año, Payno había escrito una obra más larga, Memorias del matrimonio, que recogía advertencias y observaciones costumbristas acerca de cómo las mujeres podían "hacer más duradero el amor de sus maridos". En el apartado sobre los entretenimientos domésticos, Payno no dejaba lugar a dudas sobre la que, a su juicio, era una de las principales causas del relajamiento de las costumbres femeninas en el México independiente. En su opinión, el alma de la mujer se alejaba de las "ideas de religión y piedad" cuando era expuesta a "una febril exaltación de sentimientos" que le hacían "perder el contento y la tranquilidad de la vida doméstica": en pocas palabras, a una mujer le convenía más rezar novenas que exponerse al romanticismo seductor de La nueva Eloísa, de Jean Jacques Rousseau. ${ }^{31}$ Esta reflexión sobre las lecturas peligrosas para el alma y la importancia de la piedad religiosa en la vida doméstica no era en absoluto distinta a las que podían encontrarse en los manuales de párrocos y confesores, lo cual nos lleva a una pregunta interesante: ¿por qué Payno estaba asumiendo el papel de maestro de las buenas costumbres, una suerte de misionero laico y reformista? Como veremos a continuación, los jóvenes liberales de la generación de la Reforma no dudaron en asumir este papel porque, para ellos, la corrupción de la sociedad era, ante todo, un reflejo de la corrupción e indolencia del clero, esto es, del cuerpo social que tradicionalmente había estado encargado de enderezar las costumbres y facilitar el acceso de los fieles al auxilio de los sacramentos. Enfrentados a una Iglesia jerárquica que parecía renuente a cumplir su tarea evangélica, los liberales se creían llamados a construir una nueva Cristiandad mexicana a golpes de legislación.

29 Ibídem, 269-271.

30 Ibídem, 270-271.

31 Manuel Payno, "Memorias sobre el matrimonio" (publicado por primera vez en El Museo Mexicano, t. II, 1843), en Boris Rosen, comp., 1996: 290-292. 
La mejor expresión del proyecto de reformar las costumbres mediante la reforma del clero se encuentra en un par de artículos de Francisco Zarco, titulados, justamente, "Abusos en materias eclesiásticas. Necesidad de una reforma". Publicados en El Siglo Diez y Nueve los días 6 y 17 de noviembre de 1855 , es decir, a los pocos meses de instalado el gobierno revolucionario de Juan Álvarez, ambos textos anuncian claramente cuál sería el común denominador de las medidas que impulsaría el liberalismo triunfante hasta el estallido de la guerra civil. Es muy importante advertir que, para Zarco, el deseo de reformar la Iglesia no podía ni debía atribuirse a un "espíritu de impiedad, de irreligiosidad o de libertinaje". En su opinión, "nuestro siglo, nuestra época, nuestro país", eran "eminentemente religiosos": a diferencia de otras naciones modernas, en México ya había pasado, "para siempre", ese "corto período de incredulidad o de escepticismo". Por el contrario, añadía Zarco, la Reforma se enmarcaba en una verdadera resurrección de las creencias cristianas, las cuales, gracias a la "libre discusión", habían renacido "más esclarecidas, más depuradas de las supersticiones con que se ofuscaba la fe de nuestros antepasados". ${ }^{32}$ Así, lejos de proponer una secularización de las conciencias, lo que Zarco deseaba era desterrar para siempre los abusos eclesiásticos, de modo que la fe cristiana pudiera mostrar nuevamente su enorme poder civilizatorio:

El cristianismo ha hecho un servicio inmenso a la humanidad y la civilización, destruyendo la idolatría de los indios, y con ella el canibalismo y los sacrificios de víctimas humanas; mejorando notablemente la triste condición de la mujer, aboliendo el divorcio o el repudio y la poligamia, y restituyendo así a la mujer indígena la dignidad de madre y esposa. ${ }^{33}$

En un tono muy similar al de Manuel Payno, Zarco abogaba por mejorar la instrucción religiosa de un pueblo desordenado y fiestero, demasiado acostumbrado a "la superstición, la inmoralidad y la ignorancia". ${ }^{34}$ En efecto, mientras que "Ios protestantes y los católicos de otras naciones" consagraban el domingo a "las prácticas religiosas, a la lectura de la Biblia, a la meditación y al recogimiento", en México ese día santo estaba destinado "a ruidosas festividades religiosas y a la orgía de la embriaguez". ${ }^{35}$ A su juicio, el primer responsable de tal corrupción de las costumbres era el clero, el cual, por su mal ejemplo, su escasa preparación y su avaricia infinita, había promovido que "millares de familias" arruinasen "su fortuna y la pureza y simplicidad de sus costumbres" en toda clase de excesos devocionales. ${ }^{36}$ De manera particular, Zarco enfatizaba la prevalencia de cuatro grandes delitos en México -el adulterio, el incesto, el estupro y el rapto- y los atribuía directamente al "celibato" forzoso en que vivían todos aquellos hombres y mujeres que

32 Francisco Zarco, "Abusos en materias eclesiásticas. Necesidad de una reforma (I)", en Boris Rosen, comp., 1991. Francisco Zarco. Periodismo político y social. 6: 415. México: Centro de Investigación Científica Ing. Jorge L. Tamayo, A.C.

${ }_{33}$ Francisco Zarco, "Abusos en materias eclesiásticas. Necesidad de una reforma (II)", en Boris Rosen, comp., 1991: 417.

\footnotetext{
34 Ibídem, 432.

35 Ibídem, 433.

36 Ibídem, 430.
}

no podían reunir el caudal suficiente para cubrir los gastos que implicaba una boda religiosa:

El adulterio, el incesto, el estupro y rapto fueron siempre en México delitos muy comunes... esta inmoralidad ha sido el resultado de la escasez de recursos en que han vivido las clases más numerosas de la sociedad, lo que ha obligado a millares de hombres y mujeres a permanecer en el celibato [...] en las clases más numerosas y también las más productivas de la sociedad, los labradores, los artesanos, menestrales y jornaleros, había también muy pocos matrimonios comparados con la población; de los labradores y jornaleros del campo, los más vivían y viven aún solteros, porque sus jornales no son suficientes para mantener una familia, no les bastan ni aún para pagar los excesivos derechos parroquiales que les exigen los curas por bendecir su matrimonio y practicar las diligencias necesarias para su celebración. Examinad con atención los libros parroquiales, y veréis por ellos cuán numerosos son en todos los curatos los hijos ilegítimos, siendo de advertir que un gran número de ellos son incestuosos, adulterinos, y algunos de ellos sacrílegos; esto basta para conocer la horrible corrupción de las costumbres $[\ldots]^{37}$

El peor fruto de los vicios clericales había sido, entonces, la profusión de "uniones vagas y pasajeras, o lo que es lo mismo, el libertinaje de los hombres y la prostitución de la mujeres". ${ }^{38}$ De ahí que, para enfrentar las "causas radicales de esa grande desmoralización" en que vivían los mexicanos, fuera necesario primero "reformar la disciplina eclesiástica, hasta restituirle su santidad, su sencillez y pureza primitivas". ${ }^{39}$ Este programa reformista suponía necesariamente otorgarle al Estado amplios poderes de intervención en la vida interna de la Iglesia, particularmente en la administración de sus bienes y en la determinación de los derechos u "obvenciones" que el clero parroquial exigía a cambio de sus servicios. No está de más añadir que en este último punto radicaba uno de los aspectos más atractivos del proyecto liberal para el grueso de la población, pues los frecuentes choques entre párrocos y feligreses por el cobro excesivo de derechos habían dado lugar a una infinidad de litigios en los tribunales eclesiásticos durante décadas. ${ }^{40}$ Esta conflictiva realidad ayuda a entender por qué los liberales de la Reforma convirtieron el viejo reclamo de regular las obvenciones parroquiales en la pieza fundamental de su propuesta para incrementar el número de matrimonios y, con ello, regenerar las costumbres de la sociedad mexicana.

Francisco Zarco no fue el primero ni el único en vincular el problema de las obvenciones parroquiales con el presunto relajamiento moral de los mexicanos. Entre enero de 1833 y abril de 1834, por ejemplo, el joven Ponciano Arriaga

37 Ibídem, 430-431.

38 Ibídem, 431.

39 Zarco, "Abusos en materias eclesiásticas. Necesidad de una reforma (I)": 413 .

40 Sobre el problema de las obvenciones parroquiales, véase González Navarro, M. 1983. Anatomía del poder en México, 1848-1853: 95-106 México: El Colegio de México; O’Hara, M. D. 2010. A Flock Divided: Race, Religion, and Politics in Mexico, 1749-1857: 204-217 Durham: Duke University Press; Bravo Rubio, B. 2013. La gestión episcopal de Manuel Posada y Garduño. República católica y Arzobispado de México, 1840-1846: 121-161. México: Porrúa Print; y Ornelas Hernández, M., 2011. "La política liberal y las obvenciones parroquiales en el Obispado de Michoacán, 1821-1860”, Hispania Sacra, vol. LXIII, no. 128: 681-706 
había dedicado una serie de artículos al mismo tema en $E l$ Yunque de la Libertad, el periódico oficial del gobierno liberal de San Luis Potosí. En típica prosa anticlerical, Arriaga había culpado al clero del terrible abandono espiritual en que se encontraban los pueblos del estado, pues en muchas comunidades no había sacerdotes y, en donde sí los había, estos no cumplían sus dos deberes esenciales: predicar la doctrina y administrar los sacramentos. ${ }^{41}$ En su opinión, el peor pecado de aquellos hombres que "habiendo muerto para el mundo, son más mundanos que otros muchos" era pretender que tenían un "derecho divino" a imponer contribuciones por la celebración de bautizos, bodas y entierros. ${ }^{42}$ En lo que hace al matrimonio, insistía Arriaga, el tradicional cobro de obvenciones no sólo era contrario a las prerrogativas de la autoridad civil -a la que correspondía regular el matrimonio en todo aquello que excediera la órbita espiritual-, sino también una práctica simoníaca, absolutamente opuesta a la moral cristiana:

En nuestro humilde juicio no sólo se deben minorar los derechos de los matrimonios, sino extinguir, porque el pagar por casarse se opone al vers. 27 del Génesis que citamos al principio. El hombre fue creado con la bendición de Dios, para crecer, multiplicar, y henchir la tierra, y el que no tiene para pagar los derechos de matrimonio queda fuera de la creación y no se contempla por del linaje de Adán. ¿Serán creyentes los sostenedores del pago de derechos? El Génesis los califica. ${ }^{43}$

Casi veinte años más tarde, en marzo de 1851, el entonces senador por Michoacán, Melchor Ocampo, desató un agrio debate nacional tras publicar una durísima "Representación sobre reforma del arancel de obvenciones parroquiales", en la que igualmente denunciaba el descuido de los deberes clericales y el correspondiente abandono espiritual en que se hallaban la inmensa mayoría de los feligreses. Según Ocampo, el cobro excesivo de obvenciones había creado una nueva "servidumbre de la gleba" en México, pues muchos peones no podían pagar su boda y, para no incurrir en pecado, se veían obligados a pedir el socorro financiero de sus patrones en las haciendas, con lo que aumentaban aún más su deuda y su pobreza. ${ }^{44}$ Por si esto fuera poco, el abuso en el cobro de derechos parroquiales también había nulificado todos los intentos de la legislación civil para promover el matrimonio y, con ello, remover las causas profundas de la inmoralidad reinante:

Todas las leyes civiles, en la parte de la civilización cristiana a que pertenecemos, han impulsado de cuantos modos ha estado al alcance de los diversos legisladores, el matrimonio. Exenciones a los recién casados, privilegios a los que tengan familia, derechos de sucesión, aún al grado que coartan la libertad natural de la propiedad, se

41 Arriaga, P. 1992. Obras completas. Volumen I: La Experiencia Potosina, 1: 141-160, 189-192. México: UNAM / Departamento del Distrito Federal.

42 Ídem, 147, 170-176.

43 Ídem, 180.

44 Melchor Ocampo, "Representación sobre reforma del arancel de obvenciones parroquiales" (8 de marzo de 1851), en Ocampo, M. 1985. Obras completas de Don Melchor Ocampo. Tomo II. La polémica sobre las obvenciones parroquiales en Michoacán: 254-255. Morelia: Comité Editorial del Gobierno de Michoacán. han calculado sobre el plan de favorecer aquel contrato. La razón es muy perceptible para los que creemos que la familia es la base de la sociedad civil, y que el Estado tiene interés en que los hijos sean mantenidos y educados convenientemente. Pues bien, un señor cura que no quiere sujetarse al arancel y pida a los pobres más de lo que conocidamente pueden dar por su matrimonio, inutiliza toda la legislación, todos los conatos del poder civil sobre este ramo. Es ésta una de las más fecundas causas de hijos ilegítimos, de mujeres prostituidas y de adulterios: esto último principalmente en los campos, en donde con suma frecuencia se ven, huyendo de uno en otro punto, una persona célibe con una casada. ${ }^{45}$

Estos antecedentes permiten entender por qué la introducción del matrimonio civil no fue incluida en la agenda reformista del Congreso Constituyente de 1856-57, ni en la de las administraciones liberales de Juan Álvarez e Ignacio Comonfort. En lugar de la total separación Iglesia-Estado, que nadie propuso antes de 1859 , el objetivo inicial del partido liberal era otro: dotar al Estado de los poderes necesarios para emprender una reforma profunda de la Iglesia, en los mismos términos planteados por Francisco Zarco. Este objetivo se alcanzó mediante el artículo 123 de la Constitución de 1857, el cual concedió a los poderes federales una amplia facultad de intervención en "materias de culto religioso y disciplina externa". Apoyándose en esta facultad, el presidente Comonfort decretó dos importantes reformas directamente relacionadas con el matrimonio. La primera fue la Ley Orgánica del Registro Civil, publicada el 27 de enero de 1857. De acuerdo con esta ley, todo matrimonio debía registrarse ante el "oficial del estado civil" una vez concluida la celebración del sacramento "ante el párroco y previas las solemnidades canónicas"; si dicho registro no tenía lugar dentro de las 48 horas posteriores a la celebración, los consortes serían multados y su matrimonio no produciría efectos civiles. De igual manera, los párrocos tenían la obligación de informar a la autoridad civil de todos los matrimonios celebrados en su jurisdicción dentro de un plazo de 24 horas, bajo pena de multa. ${ }^{46}$ La segunda reforma, más radical que la anterior, fue la Ley de Derechos y Obvenciones Parroquiales, publicada el 11 de abril del mismo año. ${ }^{47}$ Este decreto prohibía, bajo pena de multa o destierro, el cobro de derechos en "los bautismos, amonestaciones, casamientos y entierros de los pobres", categoría que englobaba a toda persona que no obtuviera por su trabajo o por cualquier título honesto "más de la cantidad diaria indispensable para la subsistencia". 48

Las leyes de 27 de enero y 11 de abril de 1857 recogían la solución liberal a la crisis del orden familiar en México: mientras que el Registro Civil facilitaría la vigilancia estatal de las labores parroquiales, la supresión de los cobros por servicios sacramentales a los pobres permitiría que la gran

45 Ibídem, 253-254.

46 Arts. 65, 71-74 y 78 de la Ley Orgánica del Registro Civil (27 de enero de 1857), en Documentos básicos de la Reforma, 1854-1875. 1982. Tomo II: 95-107. México: Partido Revolucionario Institucional.

47 Mejor conocida como "Ley Iglesias", en referencia a su autor, el ministro de Justicia José María Iglesias.

48 Arts. 1-8 de la Ley sobre Obvenciones y Derechos Parroquiales (11 de abril de 1857), en Documentos básicos de la Reforma, 1854-1875. Tomo II: 172-174. 
mayoría de la población pudiera formar una familia propiamente dicha. El éxito de ambas leyes, sin embargo, dependía en último término de la buena voluntad de los curas, y el gobierno liberal no supo reconocer a tiempo la amplitud y la intensidad de la oposición clerical a su programa de reformas. Entre marzo y abril de 1857 , los obispos de la república prohibieron terminantemente que los feligreses de sus respectivas diócesis prestasen el tradicional juramento de obediencia a la nueva Constitución liberal, so pena de excomunión. En caso de haber jurado, el individuo en cuestión tendría que retractar públicamente su juramento, o se le privaría indefinidamente de todos los sacramentos e incluso de la cristiana sepultura. Se trataba de una medida extrema frente a un conjunto de reformas que el Episcopado consideraba atentatorias de la autonomía eclesiástica y contrarias al carácter "exclusivamente católico" de la nación. ${ }^{49}$ Confiados en que la reacción popular obligaría a revisar la obra del Constituyente, los obispos provocaron una crisis aún mayor y, sin quererlo, llevaron el conflicto hacia rumbos inéditos.

La oposición popular al juramento constitucional -particularmente en el centro-occidente del país-, aunada a los problemas de gobernabilidad provocados por los frecuentes choques entre el presidente Comonfort y la nueva legislatura federal, precipitaron el golpe de Estado de diciembre de 1857 y el estallido de la guerra civil a comienzos del año siguiente. La principal diferencia entre esta guerra y la larga lista de conflictos anteriores radica en que, por primera vez, el país entero se hallaba claramente dividido en dos bandos irreconciliables, definidos por su postura frente a la Constitución liberal. Esta profunda fractura en la unidad católica de la nación se hizo sentir particularmente en las celebraciones sacramentales, las cuales eran y seguirían siendo el epicentro ritual de la vida colectiva. Aunque no contamos con una cifra aproximada del número de matrimonios antes y después de la condena episcopal del juramento, los archivos estatales y diocesanos conservan numerosos expedientes de uniones que no fueron bendecidas porque el novio era "juramentado", es decir, un simpatizante abierto de la causa reformista. En su imprescindible obra Anales mexicanos, el presbítero y filósofo liberal Agustín Rivera también menciona varios casos de "matrimonios clandestinos", es decir, parejas que se presentaban súbitamente en la recámara o en la sala de la casa parroquial, declaraban ante el sorprendido párroco y dos testigos su voluntad de casarse, y, acto seguido, salían huyendo para evitarse una reprimenda por su conducta escandalosa. ${ }^{50}$ Evidentemente, esta clase de incidentes profundizaron aún más la sensación de una grave crisis moral y evidenciaron la necesidad de una solución que fuera mucho más allá de las reformas de 1857.

El 7 de julio de 1859, el presidente constitucional Benito Juárez anunció una serie de medidas -mejor conocidas como "Leyes de Reforma"- cuya finalidad sería remover

49 Al respecto, véase Mijangos y González, P. 2015. The Lawyer of the Church: Bishop Clemente de Jesús Munguía and the Clerical Response to the Mexican Liberal Reforma, Lincoln: Nebraska University Press.

50 Rivera, A. 1963. Anales mexicanos. La Reforma y el Segundo Imperio: 36-37. México: Comisión Nacional para las Conmemoraciones Cívicas de 1963. definitivamente los "diversos elementos de despotismo, de hipocresía, de inmoralidad y de desorden" que habían impedido la consolidación del orden constitucional en México. Dado que, en la versión liberal, la fuente última de todos los males de la nación era el clero católico, el eje rector del nuevo paquete de reformas sería el establecimiento de "la más perfecta independencia entre los negocios del Estado y los puramente eclesiásticos". De este principio se derivaba la proclamación de la libertad de cultos, así como la redefinición de los derechos parroquiales como una remuneración que, en lo sucesivo, sería "objeto de convenios libres" entre los ministros de culto y su feligresía. ${ }^{51}$ Esta transformación radical de las relaciones Iglesia-Estado exigía también una reforma del régimen jurídico del matrimonio, misma que se llevó a cabo mediante la Ley del Matrimonio Civil, publicada en Veracruz el 23 de julio siguiente. Tradicionalmente atribuida a Melchor Ocampo, esta ley definió el matrimonio como un contrato que sólo se podría contraer "lícita y válidamente ante la autoridad civil". Las parejas casadas conforme a la ley podrían "recibir las bendiciones de los ministros de su culto", pero sólo el matrimonio civil surtiría efectos legales. ${ }^{52}$

Aunque la Ley del 23 de julio de 1859 abría las puertas a un proceso inédito de secularización de la sociedad mexicana, sus disposiciones seguían estando inspiradas en la tradición del reformismo anticlerical -y cristiano- a la que pertenecían los ideólogos del partido liberal. Como reconocía el ministro de Justicia del gobierno constitucional, Manuel Ruiz, esta ley era una respuesta extraordinaria a los esfuerzos del clero reaccionario para "procurar la inobediencia a las leyes de la República". La gran mayoría de los curas, en efecto, estaba negando "las bendiciones de la Iglesia a muchas personas, por el solo hecho de mostrarse fieles al juramento que prestaron a la Constitución y a las leyes". ${ }^{53} \mathrm{El}$ empleo abusivo de la "gracia sacramental del matrimonio" había provocado toda clase de incidentes escandalosos y, sobre todo, estaba minando la base misma de la sociedad civil:

Con semejante doctrina... se ha profanado la virtud espiritual del matrimonio por los mismos que están destinados a procurarla; se ha impedido la unión de los esposos por los mismos a quienes el soberano dio misión de testificarla, y se ha minado a la sociedad en su parte más esencial, que es la organización de las familias, por los mismos que tienen el estricto deber de predicar la moral y de procurar que los creyentes vivan en la santidad y en la justicia..$^{54}$

Para no dejar lugar a dudas sobre la ortodoxia de la nueva ley, el ministro de Gobernación, Melchor Ocampo, también envió una circular explicando que esta reforma

51 "Manifiesto del Gobierno Constitucional a la Nación" (7 de julio de 1859), en Documentos básicos de la Reforma, 1854-1875. Tomo II: 267-268.

52 Arts. 1 y 30 de la Ley del Matrimonio Civil (23 de julio de 1859), en Documentos básicos de la Reforma, 1854-1875. Tomo II: 292 y 296.

53 Manuel Ruiz, "Circular del Ministerio de Justicia, Negocios Eclesiásticos e Instrucción Pública sobre la Ley del Matrimonio Civil" (23 de julio de 1859), en Documentos básicos de la Reforma, 1854-1875. Tomo II: 296.

54 Ibídem, p. 297. 
compartía el mismo objetivo que había guiado los trabajos del Concilio de Trento en el siglo XVI: poner "un coto a los innumerables abusos" que se presentaban en la celebración del sacramento nupcial. Según Ocampo, los decretos conciliares habían sido adecuados para una época en la que "las gentes de la Iglesia eran las únicas de la generalidad que algo sabían". Los progresos de la sociedad civil y la historia reciente, sin embargo, habían mostrado la necesidad de "una nueva Reforma, por los abusos que una autoridad no vigilada y una posesión no contradicha por más de trescientos años han introducido en el clero". Sin ésta, "el más robusto fundamento de la sociedad, la familia legítima, quedaría servilmente subyugada". ${ }^{55}$

¿En qué consistió exactamente la reforma de 1859? La Ley del Matrimonio Civil introdujo dos cambios fundamentales. El primero y de mayor trascendencia, fue la afirmación de la jurisdicción exclusiva del Estado sobre el derecho familiar: en adelante, el matrimonio sólo tendría validez y efectos jurídicos en el marco de la legislación civil. El segundo, derivado del anterior, consistió en asignar al "encargado del Registro Civil" la misma función que antes tenía el párroco: la de "un simple testigo condecorado y fidedigno que autoriza el acto y que vigila, en sus preliminares, sobre que el matrimonio no se contraiga entre las personas y con las circunstancias que la sociedad ha prohibido porque le serían perjudiciales". ${ }^{56}$ En todo lo demás, sin embargo, no se hicieron mayores modificaciones. El catálogo de impedimentos para contraer matrimonio, por ejemplo, se mantuvo prácticamente intacto, aún cuando uno de los objetivos de la ley era lograr que los "enlaces legítimos" fueran "más fáciles" y "más numerosos". ${ }^{57}$ La continuidad del régimen anterior se aprecia sobre todo en el mantenimiento de la indisolubilidad conyugal (el "divorcio" seguiría siendo una mera separación temporal de los esposos) y en la confirmación de los papeles diferenciados que tradicionalmente correspondían al hombre y la mujer en el ámbito doméstico. A este respecto, el artículo 15 de la ley -la célebre "epístola de Melchor Ocampo"- condensa la visión que tenían los reformadores sobre la familia e ilustra a la perfección su deseo de moralizar las costumbres a través de los dictados legislativos:

El día designado para celebrar el matrimonio ocurrirán los interesados al encargado del Registro Civil, y éste... les manifestará: que éste es el único medio moral de fundar la familia, de conservar la especie y de suplir las imperfecciones del individuo, que no puede bastarse a sí mismo para llegar a la perfección del género humano.

Que éste no existe en la persona sola, sino en la dualidad conyugal. Que los casados deben ser y serán sagrados el uno para el otro, aún más de lo que es cada uno para sí. Que el hombre, cuyas dotes sexuales son principalmente el valor y la fuerza, debe dar y dará a la mujer protección, alimento y dirección, tratándola siempre como a la parte más delicada, sensible y fina de sí mismo,

55 Melchor Ocampo, "Circular de la Secretaría de Gobernación" (6 de agosto de 1859), en Ocampo, M. 1948. La religión, la Iglesia y el clero: 206-210. México: Empresas Editoriales.

56 Ibídem, 206.

57 Ruiz, "Circular del Ministerio de Justicia, Negocios Eclesiásticos e Instrucción Pública": 297. y con la magnanimidad y benevolencia generosa que el fuerte debe al débil, esencialmente cuando este débil se entrega a él, y cuando por la sociedad se le ha confiado. Que la mujer, cuyas principales dotes son la abnegación, la belleza, la compasión, la perspicacia y la ternura, debe dar y dará al marido obediencia, agrado, asistencia, consuelo y consejo, tratándolo siempre con la veneración que se debe a la persona que nos apoya y defiende, y con la delicadeza de quien no quiere exasperar la parte brusca, irritable y dura de sí mismo. Que el uno y el otro se deben y tendrán respeto, deferencia, fidelidad, confianza y ternura, y ambos procurarán que lo que el uno se esperaba del otro al unirse con él no vaya a desmentirse con la unión. Que ambos deben prudenciar y atenuar sus faltas. Que nunca se dirán injurias, porque las injurias entre los casados deshonran al que las vierte y prueban su falta de tino o de cordura en la elección, ni mucho menos se maltratarán de obra, porque es villano y cobarde abusar de la fuerza. Que ambos deben prepararse con el estudio y amistosa y mutua corrección de sus defectos a la suprema magistratura de padres de familia, para que cuando lleguen a serlo, sus hijos encuentren en ellos buen ejemplo y una conducta digna de servirles de modelo. ${ }^{58}$

Una posible explicación del notable conservadurismo de la Ley del Matrimonio Civil es que los liberales de la Reforma, "aún los más exaltados", tenían que "recurrir a un vocabulario religioso para explicarse e influir en la opinión pública". ${ }^{59}$ Este argumento es problemático no sólo porque asume a los liberales como superhombres adelantados a su tiempo -estadistas modernos y desencantados que sabían manipular el viejo lenguaje de un pueblo poco ilustrado-, sino porque menosprecia injustificadamente la inocultable dimensión religiosa del programa liberal. Si se toman seriamente el discurso y las prioridades legislativas de la generación juarista, la Reforma recobra el carácter que quisieron darle sus protagonistas: un movimiento político y al mismo tiempo religioso, centrado en la construcción de una sociedad emancipada del poder corruptor del clero, ordenada por la moral cristiana y regida por sus propias leyes y representantes. Esta dimensión religiosa del movimiento liberal se revela con nitidez en el (fallido) intento de crear una Iglesia nacional y reformada, cuya principal misión, según expresó el propio Melchor Ocampo en octubre de 1859, sería mostrar que no existía oposición alguna "entre la Constitución y los dogmas del cristianismo, entre las leyes nuevas y las primitivas doctrinas de la Iglesia". 60 Resulta por demás significativo que en esta nueva ecclesia liberal, el celibato eclesiástico sería condenado como "una invención infernal directamente opuesta a los designios de la naturaleza", y que, por el contrario, el matrimonio civil

58 Art. 15 de la Ley del Matrimonio Civil, en Documentos básicos de la Reforma, 1854-1875. Tomo II, pp. 293-294.

59 Staples, A. 2001: 219.

60 "Carta de Melchor Ocampo a Rafael Díaz Martínez, de parte de Benito Juárez" (octubre de 1859; publicada en El Monitor Republicano el 7 de octubre de 1861), reproducida en Kirk, D. 1999. "La formación de una Iglesia nacional mexicana, 1859-1872", Tesis de maestría en Estudios Latinoamericanos, Facultad de Filosofía y Letras / UNAM, apéndice A. Véase también Bastian, J. P. 1989. Los disidentes. Sociedades protestantes y revolución en México, 1872-1911: 32-35. México: Fondo de Cultura Económica; y Voekel, P. 2007. "Liberal Religion: The Schism of 1861”, en Martin Austin Nesvig, ed., Religious Culture in Modern Mexico: 78-105. Lanham: Rowman \& Littlefield Publishers. 
sería reconocido como "válido y verdadero sacramento", siempre que se llevara a cabo "entre católicos" y fuera contraído "en gracia y con las demás condiciones que quiere la Iglesia romana". ${ }^{61}$

¿Qué conclusiones pueden formularse después de este rápido vistazo a los orígenes del matrimonio civil en México? La primera es que la ley del 23 de julio de 1859 buscaba facilitar la celebración y multiplicación de los matrimonios a fin de hacer posible una profunda reforma de la sociedad mexicana. Según los liberales, la corrupción moral del pueblo era más que visible en la proliferación de relaciones libertinas, mujeres solteras e hijos ilegítimos, y la causa principal de estos males terribles era la corrupción del clero católico, que enseñaba poco y mal de la doctrina moral cristiana, y además cobraba abusivamente por la celebración del sacramento del matrimonio, "el único medio moral de fundar la familia". El objetivo central de los liberales, entonces, no era expulsar a la religión del espacio público, sino, más bien, reformar al clero para que los valores religiosos pudieran ser efectivamente observados en la vida social. Fue por ello que la Constitución de 1857 autorizó al Estado para intervenir directamente en materias de "culto religioso y disciplina externa", como la regulación de las obvenciones parroquiales y el registro de las celebraciones sacramentales. Fue sólo tras el fracaso de estas medidas, y en el contexto de una sangrienta guerra civil, que el gobierno liberal optó por ensayar una ruta inédita, decretando "la más perfecta independencia" entre la Iglesia y el Estado, y asumiendo para éste el control del matrimonio y la misión de moralizar las costumbres a través de la ley.

No es fácil ubicar con precisión las fuentes doctrinales del reformismo liberal mexicano. Es indudable que las doctrinas regalistas del siglo XVIII seguían teniendo una gran influencia a mediados del siglo XIX, y que la admiración de Zarco por "los católicos y protestantes de otras naciones" que consagraban el domingo a "la lectura de la Biblia, a la meditación y al recogimiento" demuestra la continuidad de las críticas filo-jansenistas a la religiosidad barroca, e incluso sugiere una cierta fascinación por la cultura religiosa de los Estados Unidos. La Reforma liberal mexicana, sin embargo, también puede ser vista como un episodio tardío de los movimientos reformistas y anticlericales que sacudieron periódicamente a la Cristiandad occidental desde la Baja Edad Media. Los liberales mexicanos, en efecto, dieron una nueva vida al viejo anhelo de restituir la pureza y sencillez primitivas de la Iglesia, y compartieron el escándalo de los humanistas frente a la ignorancia y venalidad del clero. Su pretensión de que el gobierno regulara y vigilara la celebración del matrimonio tampoco era nueva: como observa James A. Brundage, desde tiempos de la Peste Negra los distintos soberanos de la Cristiandad europea habían buscado intervenir con mayor fuerza en la regulación de la vida marital y la conducta sexual, pues consideraban que la Iglesia no había logrado poner un freno al adulterio, la prostitución, el

61 Arts. 4ㅇ y 5으 del "Estatuto de la Iglesia católica, Apostólica mexicana de Santa Bárbara de Tamaulipas" (12 de mayo de 1861), en Archivo Histórico del Arzobispado de México, Fondo Episcopal, Serie: Correspondencia; caja 96, exp. no. 32. concubinato y todos los demás pecados carnales que explicaban las calamidades del siglo..22 Vista a la luz de la tradición heredada, la Ley del Matrimonio Civil era vino viejo en odres nuevos.

La segunda conclusión que me atrevo a formular es una rectificación a la cronología comúnmente aceptada del proceso de secularización de la sociedad mexicana. Son legión los historiadores que suscriben una lectura teleológica del proceso de secularización, que comienza con el supuesto antropocentrismo del Renacimiento, se renueva con la lucha de los ilustrados contra el dogmatismo eclesiástico, y culmina con los esfuerzos liberales para implantar la separación Iglesia-Estado durante el siglo XIX.. ${ }^{63}$ El problema con esta lectura es que, simple y llanamente, no se ajusta a la realidad histórica: la religión -un fenómeno que no se agota en el clero-siguió estando en el centro de la vida pública por lo menos hasta finales del siglo XIX. A diferencia del positivismo, que gradualmente se convirtió en el credo oficial de las elites mexicanas después de 1867, el liberalismo de la Reforma tenía una dimensión abiertamente cristiana, como lo demuestra la historia de los orígenes del matrimonio civil. Esta conclusión es importante porque obliga a los historiadores a evitar anacronismos en sus respectivos acercamientos al siglo XIX -el liberalismo de la Reforma no es equivalente del laicismo contemporáneo- $y$, sobre todo, porque exige replantearnos varias preguntas importantes sobre este siglo crucial: el reto no está en explicar el supuesto fracaso del proyecto liberal, sino en explicar cómo, cuándo, por qué y hasta qué punto la Reforma liberal contribuyó a la eventual -e inacabada- secularización de la sociedad mexicana. ${ }^{64}$

\section{BiBLIOgRAFÍA}

\section{Archivos}

Archivo Histórico del Arzobispado de México, Fondo Episcopal, Serie: Correspondencia; caja 96, exp. no. 32.

\section{Bibliografía}

Adame Goddard, J. 2004. El matrimonio civil en México (1859-2000), México: UNAM.

Albani, B. 2008. "El matrimonio entre Roma y la Nueva España, historia y fuentes documentales (siglos XVI-XVII)", en Doris Bieñko de Peralta y Berenise Bravo Rubio, coords., De sendas, brechas y atajos. Contexto y crítica de las fuentes eclesiásticas, siglos XVI-XVIII: 167-184. México: INAH / CONACULTA.

62 Brundage, J. A. 1987. Law, Sex, and Christian Society in Medieval Europe: 487-552 Chicago: The University of Chicago Press.

63 Para un ejemplo representativo de esta lectura teleológica de la secularización, véase Galeana, P. “Prólogo: un recuento histórico sobre la secularización del Estado y de la sociedad en México", en Galeana, P. (coord.). 2010. Secularización del Estado y de la sociedad: 9-16. México: Senado de la República / Siglo XXI Editores.

64 Sobre la recepción y las consecuencias inmediatas de la Ley del Matrimonio Civil, véase Savage, M. 2009. "El laicismo en los primeros matrimonios civiles de la Ciudad de México: el inicio de una fe anónima", Históricas, no. 86: 2-18. 
Arriaga, P. 1992. Obras completas. Volumen I: La Experiencia Potosina, 1, México: UNAM / Departamento del Distrito Federal.

Arrom, S. 1985. The Women of Mexico City, 1790-1857, Stanford: Stanford University Press.

Bastian, J. P. 1989. Los disidentes. Sociedades protestantes y revolución en México, 1872-1911, México: Fondo de Cultura Económica.

Bravo Rubio, B. 2013. La gestión episcopal de Manuel Posada y Garduño. República católica y Arzobispado de México, 1840-1846, México: Porrúa Print.

Brundage, J. A. 1987. Law, Sex, and Christian Society in Medieval Europe, Chicago: The University of Chicago Press.

Carbajal, D. 2008. La población en Bolaños, 1740-1848. Dinámica demográfica, familia y mestizaje, Zamora: El Colegio de Michoacán.

Desan, S. 2004. The Family on Trial in Revolutionary France, Berkeley: University of California Press.

Documentos básicos de la Reforma, 1854-1875. 1982. Tomo /I México: Partido Revolucionario Institucional.

Escriche, J. 1837. Diccionario razonado de legislación civil, penal, comercial y forense, México:

Imprenta de Galván a cargo de Mariano Arévalo.

Febrero mejicano, o sea la librería de Jueces, abogados y escribanos, que refundida, ordenada bajo nuevo método, adicionada con varios tratados y con el título de Febrero Novísimo, dio a luz D. Eugenio de Tapia, nuevamente adicionada con otros diversos tratados, y las disposiciones del Derecho de Indias y del Patrio, por el Lic. Anastasio de la Pascua. 1834. tomo I, México: M. Galván Rivera.

Galeana, P. (coord.). 2010. Secularización del Estado y de la sociedad, México: Senado de la República / Siglo XXI Editores.

García Peña, A. L. 2006. El fracaso del amor. Género e individualismo en el siglo XIX mexicano, México: El Colegio de México / Universidad Autónoma del Estado de México.

Gonzalbo, P. (coord.). 1991. Familias novohispanas: siglos XVI al XIX, México: El Colegio de México.

Gonzalbo, P. y C. Rabell, (coords.). 1996. Familia y vida privada en la historia de Iberoamérica, México: El Colegio de México / UNAM.

González Navarro, M. 1983. Anatomía del poder en México, 1848-1853, México: El Colegio de México.

Gregory, Brad S. 2012. The Unintended Reformation: How a Religious Revolution Secularized Society, Cambridge: Harvard University Press.

Informe que el L. Juan Rodríguez de San Miguel, hizo en la E. Primera Sala de la Suprema Corte de Justicia, el 22 de Septiembre de 1846, en el recurso de fuerza interpuesto por $D$. José M. Flores, contra la dispensa de las públicas moniciones en el matrimonio que expresa, para que en él se observasen acerca de éstas las disposiciones del Tridentino, Bulas Pontificias y leyes civiles muy expresas. 1846. México: Imprenta de José Mariano Lara.
Kirk, D. 1999. "La formación de una Iglesia nacional mexicana, 1859-1872", Tesis de maestría en Estudios Latinoamericanos, Facultad de Filosofía y Letras / UNAM.

Lavrin, A. (coord.). 1989. Sexuality and Marriage in Colonial Latin America, Lincoln: University of Nebraska Press.

Lida, M. 2007. "Secularización: doctrina, teoría y mito. Un debate desde la historia sobre un viejo tópico de la socio-logía" Cuadernos de Historia. Serie Economía y Sociedad, no 9: 43-63.

Mijangos y González, P. 2015. The Lawyer of the Church: Bishop Clemente de Jesús Munguía and the Clerical Response to the Mexican Liberal Reforma, Lincoln: Nebraska University Press.

Mora, J. M. L. 1837. Obras sueltas de José María Luis Mora, ciudadano mejicano. Tomo primero, París: Librería de la Rosa.

Núñez Becerra, F. 2011. "Mujeres y matrimonio civil vistos por las Leyes de Reforma", en Celia del Palacio Montiel, coord., México durante la guerra de Reforma. Tomo II. Contextos, prácticas culturales, imaginarios y representaciones, Xalapa: Universidad Veracruzana: 139-153.

O'Hara, M. D. 2010. A Flock Divided: Race, Religion, and Politics in Mexico, 1749-1857, Durham: Duke University Press.

Ocampo, M. 1948. La religión, la Iglesia y el clero, México: Empresas Editoriales.

Ocampo, M. 1985. Obras completas de Don Melchor Ocampo. Tomo II. La polémica sobre las obvenciones parroquiales en Michoacán, Morelia: Comité Editorial del Gobierno de Michoacán.

Ornelas Hernández, Moisés, 2011. "La política liberal y las obvenciones parroquiales en el Obispado de Michoacán, 1821-1860", Hispania Sacra, vol. LXIII, no. 128: 681-706.

Rivera, A. 1963. Anales mexicanos. La Reforma y el Segundo Imperio, México: Comisión Nacional para las Conmemoraciones Cívicas de 1963.

Rosas Salas, S. F. 2013. "La Iglesia mexicana en tiempos de la impiedad: Francisco Pablo Vázquez, 1769-1847", tesis de doctorado en Ciencias Humanas, El Colegio de Michoacán.

Rosen, B. (comp.). 1991. Francisco Zarco. Periodismo político y social. 6, México: Centro de Investigación Científica Ing. Jorge L. Tamayo, A.C.

Rosen, B. (comp.). 1996. Manuel Payno. Obras completas, tomo XIV, México: CONACULTA.

Saether, S. A. 2003. "Bourbon Absolutism and Marriage Reform in Late Colonial Spanish America", The Americas, vol. 59, no. 4: 475-509.

Savage, M. 2009. "El laicismo en los primeros matrimonios civiles de la Ciudad de México: el inicio de una fe anónima", Históricas, no. 86: 2-18.

Staples, A. 2001. "El matrimonio civil y la epístola de Melchor Ocampo, 1859", en Pilar Gonzalbo, (coord.), Familias iberoamericanas. Historia, identidad y conflictos. 217-229. México: El Colegio de México. 
Vallarta, I. 1897. Obras completas del C. Lic. Ignacio L. Vallarta, tomo sexto, México: José Joaquín Terrazas e hijas, imp.

Van Kley, D. K. 1996. The Religious Origins of the French Revolution: From Calvin to the Civil Constitution, 1560-1791, New Haven: Yale University Press.

Voekel, P. 2002. Alone before God: The Religious Origins of Modernity in Mexico, Durham: Duke University Press.
Voekel, P. 2007. "Liberal Religion: The Schism of 1861", en Martin Austin Nesvig, ed., Religious Culture in Modern Mexico: 8-105. Lanham: Rowman \& Littlefield Publishers.

Warnholtz Bustillos, C. 1996. Manual de derecho matrimonial canónico, México: Universidad Pontificia de México.

Zarco, F. 1956. Historia del Congreso Extraordinario Constituyente, 1856-1857, México: El Colegio de México. 